\title{
Lymphangiectatic Kaposi's sarcoma in a patient with AIDS
} Sarcoma de Kaposi linfangiectásico em paciente com Aids

\author{
Mônica Santos ${ }^{1}$ \\ Luciana Mendes² \\ Sinésio Talhari ${ }^{4}$
}

\author{
Virginia Vilasboas ${ }^{2}$ \\ Carolina Talhari ${ }^{3}$
}

\begin{abstract}
Kaposi's sarcoma is a malignant disease that originates in the lymphatic endothelium. It has a broad spectrum of clinical manifestations. Its four distinct clinical forms are: classic, endemic, iatrogenic and epidemic Kaposi's sarcoma. In non-HIV-associated Kaposi's sarcoma, the disease is typically limited to the lower extremities, but in immunodeficient patients, it is a multifocal systemic disease. The clinical course of the disease differs among patients, ranging from a single or a few indolent lesions to an aggressive diffuse disease. Advanced Kaposi's sarcoma lesions, typically those on the lower extremities, are often associated with lymphedema. In this paper, we report a case of a patient with a rare form of AIDS-associated Kaposi sarcoma called lymphangiectatic Kaposis's sarcoma.
\end{abstract}

Keywords: Acquired immunodeficiency syndrome; Lymphedema; Murine acquired immunodeficiency syndrome; Sarcoma, kaposi

Resumo: O sarcoma de Kaposi é uma neoplasia originária do endotélio linfatico, que apresenta um amplo espectro de manifestações, com quatro formas clínicas: sarcoma de Kaposi clássico, endêmico, iatrogêncio e epidêmico ou associado ao HIV. Em pacientes imunocompetentes, a doença é tipicamente limitada às extremidades. Porém em pacientes imunideprimidos, o sarcoma de Kaposi é uma doença sistêmica multifocal. Apresenta cursos clínicos diferentes, desde simples lesões cutâneas isoladas até lesões agressivas e difusas, com ou sem envolvimento sistêmico. Lesões avançadas de sarcoma de Kaposi, principalmente as localizadas nas extremidades, podem apresentar linfedema. Neste trabalho, reportamos caso de paciente com forma rara de Sarcoma de Kaposi associado a Aids, chamada de sarcoma de Kaposi linfangiectásico.

Palavras-chave: Linfedema; Sarcoma de kaposi; Síndrome de Imunodeficiência Adquirida; Síndrome de imunodeficiência adquirida murina

\section{INTRODUCTION}

Kaposi's sarcoma (KS) is a neoplasm that originates in the lymphatic endothelium and has a broad spectrum of clinical manifestations. ${ }^{1}$ There are four distinct clinical forms of the disease: classic KS, endemic, iatrogenic and epidemic or HIV-associated.
The etiological agent of all forms of Kaposi's sarcoma is the human herpesvirus 8 (HHV8), also known as Kaposi's sarcoma-associated herpesvirus (KSHV). ${ }^{2}$ In classic KS, the disease is typically limited to the lower extremities, although it may be more widespread. In

Received on 16.02.2012.

Approved by the Advisory Board and accepted for publication on 09.04.2012.

* Study conducted at Amazonas Tropical Medicine Foundation (FMTAM)) - Manaus (AM), Brazil.

Financial Support: None.

Conflict of Interests: None.

PhD in Tropical Medicine, Dermatologist Physician at the Alfredo da Matta Foundation (FUAM) and Professor of Dermatology at Amazonas State University (UEA) and Nilton Lins University - Manaus (AM), Brazil.

MD, Dermatology Physician at the Amazonas Tropical Medicine Foundation (FMTAM), Manaus (AM), Brazil.

$\mathrm{PhD}$ in Tropical Medicine, Professor of Dermatology at Amazonas State University (UEA) and Nilton Lins University - Manaus (AM), Brazil.

PhD in Dermatology, Professor of Dermatology at Nilton Lins University - Manaus (AM), Brazil. 
immunodeficient patients, such as patients with AIDS or those who have undergone a solid organ transplant, KS is a multifocal systemic disease. All clinical forms may present with lymphedema due to blockage of lymph vessels, changes in the permeability of the lymphatics, regional lymph node involvement and increased inflammatory cytokines. However, this clinical manifestation is more frequent in classic KS. ${ }^{3}$ Most skin lesions show a typical histological picture, but several histological variants, including lymphangiectatic KS, have recently been described. ${ }^{4}$ We report the case of a patient with a rare form of Aids-associated KS, without visceral involvement, presenting with an unusual clinical and histopathological picture called AIDS-associated lymphangiectatic KS.

\section{CASE REPORT}

In 2001, a 32-year-old male was referred to the department of dermatology reporting a history of lesions in the proximal right thigh. A skin biopsy was performed and suggested diagnosis of KS. A partial improvement was noted when antiretroviral therapy (TARV) was started, but the patient was lost to followup. At diagnosis, CD4+ T-cell count was 409 cells $/ \mathrm{mm}^{3}$ and viral load 76,000 copies/ $\mathrm{mm}^{3}$. In 2010, the patient returned with a worsening clinical status, including an increased number of lesions and edema around the right lower limb. Dermatological examination revealed isolated and confluent erythematousviolaceous tuberous lesions of varying sizes as well as a vegetating tumor on the inner right thigh (Figures 1 and 2). Histopathological examination revealed intercellular epidermal edema, proliferation of spindle cells, neoangiogenesis and large dilated intratumoral and peritumoral thin-walled lymphatic vessels (Figure 3). Magnetic resonance imaging showed a volumetric increase in the diameter of the entire right thigh associated with severe edema of the entire subcutaneous tissue and a heterogeneous, hypodense area in the proximal right thigh (Figure 4). Lymphangiocintigraphy revealed bilateral retention of the radiotracer, which was more pronounced in the right lower limb, with signs of lymphatic leakage (Figure 5). CT scan of the skull and chest showed no abnormalities and the endoscopy was normal. The patient was referred to a specialized cancer treatment center, where he resumed chemotherapy with paclitaxel, with partial reduction of edema and lesions.

\section{DISCUSSION}

AIDS-associated KS is a tumour of lymphatic endothelial origin that affects mucocutanous sites, but may also involve internal organs. The condition usually appears first as pink, purple, red or brown/black nodules or patches on the skin or mucosa. ${ }^{5}$ The clini-

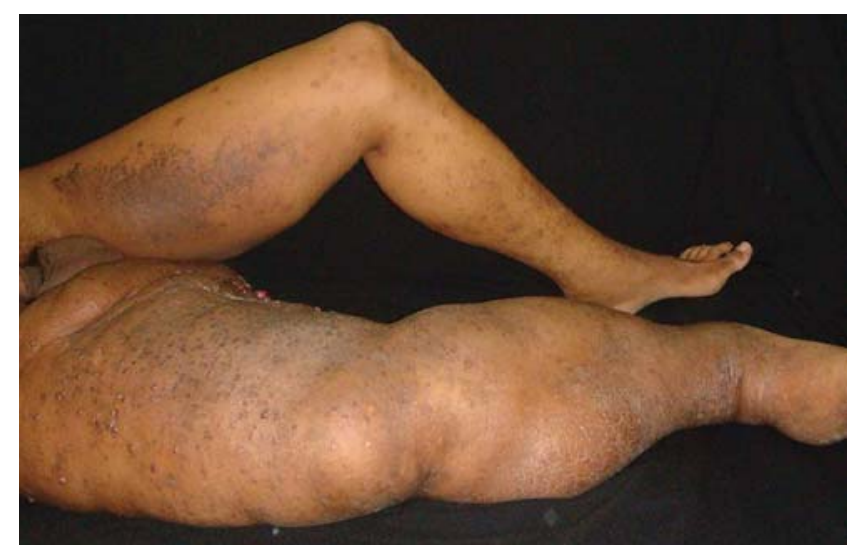

FIGURE 1: Isolated and confluent erythematous-violaceous tuberous lesions of varying sizes with substantial edema formation in the right leg
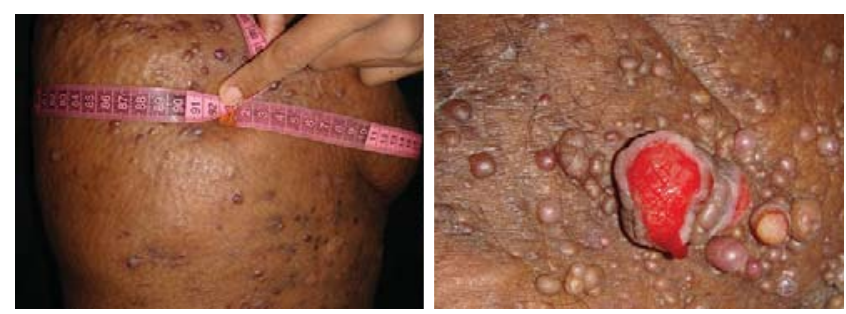

FIGURE 2: Isolated and confluent erythematous-violaceous tuberous lesions of varying sizes, and a vegetating tumor on the inner right thigh
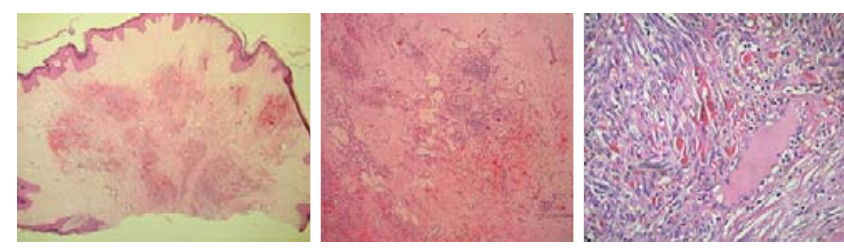

FIGURE 3: Intercellular epidermal edema, proliferation of spindle cells, neoangiogenesis and there are large dilated intratumoral and peritumoral thin-walled lymphatic vessels
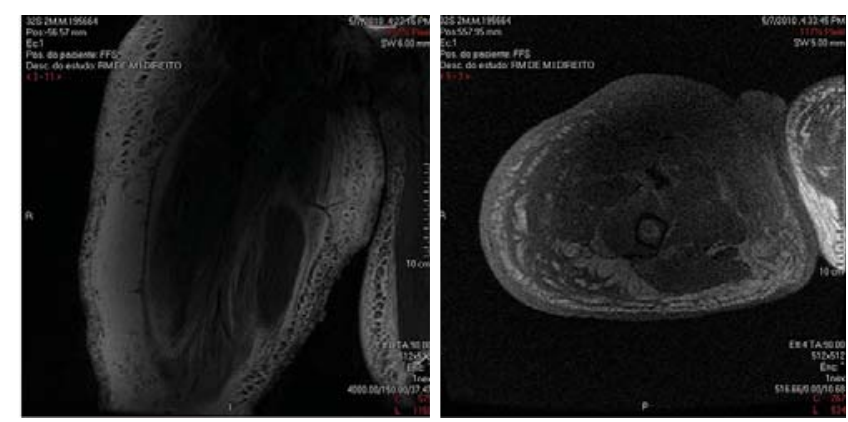

FIGURE 4: Magnetic resonance imaging showed a volumetric increase in the diameter of the entire right thigh associated with severe edema of the entire subcutaneous tissue and a heterogeneous, hypodense area in the proximal right thigh 


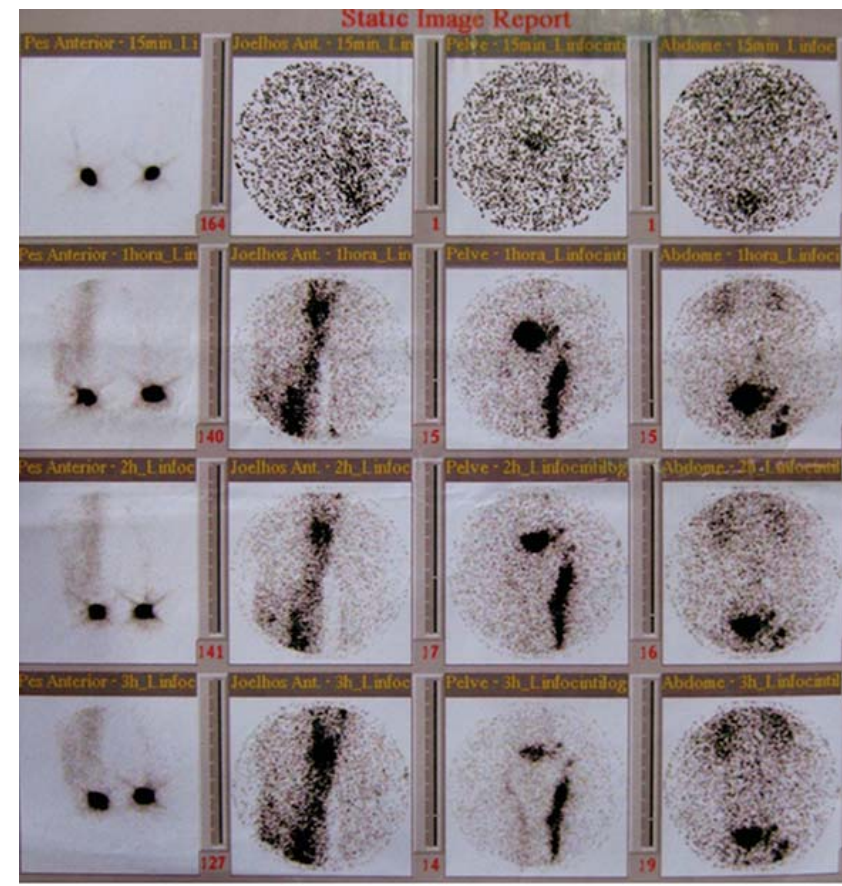

FIGURE 5: Lymphangioscintigraphy revealed bilateral retention of the radiotracer, which was more pronounced in the right lower limb, with signs of lymphatic leakage

cal course of the disease differs among patients, ranging from a single or a few indolent lesions to an aggressive diffuse disease that can rapidly cause severe complications. ${ }^{6}$ Extensive AIDS-associated KS lesions, typically those on the lower extremities, are often associated with lymphedema. In this setting, lymphedema may be due to lymphatic obstruction,

\section{REFERENCES}

1. Mohanna S, Sanchez J, Ferrufino JC, Bravo F, Gotuzzo E. Lymphangioma-like Kaposi's sarcoma: report of four cases and review. J Eur Acad Dermatol Venereol. 2006;20:1010-1

2. Dupuy S, Lambert M, Zucman D, Choukem S, Tognarelli S, Pages C, et al. Human Herpesvirus 8 (HHV8) Sequentially Shapes the NK Cell Repertoire during the Course of Asymptomatic Infection and Kaposi Sarcoma. PLoS Pathogens. 2012;8:1-15.

3. Safai B, Johnson KG, Myskowski PL, Koziner B, Yang SY, Cunningham-Rundles S, et al. The natural history of Kaposi's sarcoma in the acquired immunodeficiency syndrome. Ann Intern Med. 1985;103:744-50.

4. Davis DA, Scott DM. Lymphangioma-like Kaposi's sarcoma: Etiology and literature review. J Am Acad Dermatol. 2000;43:123-7.

5. Costa IMC, Menezes FG, Hajjar L, Salaro CP, Matos RMC. Sarcoma de Kaposi clássico: relato de caso. An Bras Dermatol. 2001;76:195-9.

6. Antman K, Chang Y. Kaposi's Sarcoma - Review Article. N Engl J Med. 2000;342:1027-38. altered lymphatic drainage, leakage from dilated lymphatics or regional lymph node involvement. In addition to the factors mentioned previously, the development of lymphedema in KS lesions may be attributed to the HHV-8-induced exuberant proliferation of endothelial cells that may lead to the occlusion of lymphatic lumens. ${ }^{7}$ Clinical and histological lymphedematous variants of AIDS-associated KS have been described more recently. These include variants associated with ectatic lymphatics (as lymphangioma-like and lymphangiectatic KS), and variants with subepidermal and intraepidermal edema (as bullous KS). Lymphangiectatic and lymphangioma-like KS are associated with ectatic lymphatics. However, in lymphangiectatic KS there were large dilated intratumoral and peritumoral thin-walled lymphatic vessels. ${ }^{8}$ In HIV-infected patients, KS is one of the indications for starting TARV. TARV has significantly changed the morbidity and mortality associated with KS and has also reduced its incidence. ${ }^{9}$ Local treatment modalities (intralesional vinblastine, cryotherapy, laser and radiation) are useful if skin or mucosal lesions are few and there is no systemic involvement. Indications for systemic treatment of KS are visceral involvement, extensive KS-associated lymphedema, extensive and rapidly progressive cutaneous KS and failure to respond to local treatment. Anthracyclines (doxorubicin and daunorubicin) and paclitaxel are agents used to treat KS. Other systemic treatment modalities include interferon-alpha and combination chemotherapies with adriamycin, bleomycin plus vincristine or vinblastine. ${ }^{10}$ In this paper we report a case of Aids-associated KS, without visceral involvement, with intense lymphatic impairment and a rare histological variant.

7. Feller L, Masipa JN, Wood NH, Raubenheimer EJ, Lemmer J. The prognostic significance of facial lymphoedema in HIV-seropositive subjects with Kaposi sarcoma. AIDS Res Ther. 2008;5:2.

8. Grayson W, Pantanowitz L. Histological variants of cutaneous Kaposi sarcoma. Diagn Pathol. 2008;3:31.

9. Schwartz RA. Kaposi's sarcoma: an update. J Surg Oncol. 2004;87:146-51.

10. Dongre A, Montaldo C. Kaposi's sarcoma in an HIV-positive person successfully treated with paclitaxel. Indian J Dermatol Venereol Leprol. 2009;75: 290-2.

\section{MAILING ADDRESS: \\ Mônica Santos}

Av. Djalma Batista, 1661, Shopping Millennium, Torre médica, salas 609-610 - Chapada 69050-010 Manaus-Am,

Brazil.

E-mail:m.n.souza.santos@gmail.com

How to cite this article: Santos M, Vilasboas V, Mendes L, Talhari C, Talhari S. Lymphangiectatic Kaposi's sarcoma in a patient with AIDS. An Bras Dermatol. 2013;88(2):276-8. 